\title{
Using Plastic Waste in a Circular Economy Approach to Improve the Properties of Bituminous Binders
}

\author{
Fernando C. G. Martinho ${ }^{1, *}$, Luís G. Picado-Santos ${ }^{2} \mathbb{D}$, Francisco M. S. Lemos ${ }^{1}$, Maria Amélia N. D. A. Lemos ${ }^{1}$ \\ and Everton R. F. Santos ${ }^{1}$ (D) \\ 1 CERENA-Department of Chemical Engineering, Instituto Superior Técnico, Universidade de Lisboa, \\ 1049-001 Lisboa, Portugal; francisco.lemos@tecnico.ulisboa.pt (F.M.S.L.); \\ mandal@tecnico.ulisboa.pt (M.A.N.D.A.L.); everton.santos@tecnico.ulisboa.pt (E.R.F.S.) \\ 2 CERIS, Instituto Superior Técnico, Universidade de Lisboa, 1049-001 Lisboa, Portugal; \\ luispicadosantos@tecnico.ulisboa.pt \\ * Correspondence: fernando.martinho@tecnico.ulisboa.pt
}

Citation: Martinho, F.C.G.; Picado-Santos, L.G.; Lemos, F.M.S.; Lemos, M.A.N.D.A.; Santos, E.R.F. Using Plastic Waste in a Circular Economy Approach to Improve the Properties of Bituminous Binders. Appl. Sci. 2022, 12, 2526. https:// doi.org/10.3390/app12052526

Academic Editor: Jacek Tomków

Received: 29 January 2022

Accepted: 24 February 2022

Published: 28 February 2022

Publisher's Note: MDPI stays neutral with regard to jurisdictional claims in published maps and institutional affiliations.

Copyright: (C) 2022 by the authors. Licensee MDPI, Basel, Switzerland. This article is an open access article distributed under the terms and conditions of the Creative Commons Attribution (CC BY) license (https:// creativecommons.org/licenses/by/ $4.0 /)$.

\begin{abstract}
This work aims to use wax to modify a binder employed in the paving industry. This wax can be obtained either directly or as a by-product from plastic waste's thermal cracking (pyrolysis). The study characterizes this sustainable material and the binders resulting from blending it with conventional or modified bitumen with other additives applied in the manufacture of bituminous mixtures. Different tests were used: thermogravimetric and spectroscopic analysis; consistency tests; testing of dynamic viscosity at various temperatures; and assessment of the rheologic properties of binders. As a result, several crucial findings were reached: this sustainable wax promotes changes in the viscosity of the binders, their handling temperatures can be reduced, and it contributes to some goals of the U.N. 2030 Agenda. In summary, this work allowed us to conclude that the positive effects of a suitable modification of the bituminous binders, which incorporated this wax and other additives, led to improved consistency and rheological behaviour, having provided, for example, lower temperature susceptibility and higher permanent deformation resistance.
\end{abstract}

Keywords: sustainable wax; additives; plastic waste; pyrolysis; bitumen; recycling; rheology; circular economy

\section{Introduction}

This manuscript refers to a part of a broader research project that was carried out to validate an initial hypothesis: would it be feasible and beneficial to use a waste-derived by-product, resulting from a sustainable production of middle and heavy hydrocarbons (chemical recycling), for the improvement of some properties of different binders used in bituminous mixtures for flexible pavements?

Here is described a part of the laboratory work to confirm some aspects of this hypothesis. It started with the production and characterization of waxes resulting from pyrolysis, a thermochemical process that can be used, for example, to produce liquid fuel as an alternative to refine it from fossil sources (in a specific reaction system, developed at the IST-University of Lisbon-Portugal).

The waxes were produced by thermal cracking (pyrolysis) of high-density polyethylene (HDPE) recovered from plastic waste. However, it is generally assumed that they can also be produced via co-processing with other plastic residues such as cable insulation (originating in waste from electric and electronic equipment (WEEE)), and rubber from end-of-life tires.

The produced waxes were added to four standardized types of binders (all paving bitumen), and the effect on their properties was assessed. In the first phase (described in this manuscript), the considered experimental program included, among other tests, the following: thermogravimetric and spectroscopic analysis, determination of the needle 
penetration and softening temperature, testing of dynamic viscosity, and assessment of the rheologic properties of several materials and blends.

Among other goals, the one mentioned in ninth place in the U.N. 2030 Agenda for Sustainable Development (https: / / sdgs.un.org/2030agenda, accessed on 23 February 2022) defines short/medium-term objectives centred on building more resilient infrastructure, fostering innovation, and promoting sustainable industrialization. In this sense, as explained by Russo et al. [1] when referring to the road infrastructure pavement sector, an appropriate contribution to the fulfilment of this goal can be given by the incorporation of different materials (including waste) that improve the performance of bituminous mixtures. These materials comprise not only a variety of polymers [2] (such as styrene-butadiene-styrene (SBS), poly(ethylene terephthalate) (PET), high-density polyethylene (HDPE), low-density polyethylene (LDPE), polystyrene (PS), polyurethane (PU), polypropylene (PP), crosslinked polyethylene (XLPE or PEX), acrylonitrile butadiene styrene (ABS), ethylene-vinyl acetate (EVA), styrene-isoprene-styrene (SIS), and others), Sulphur, mineral acids, and sustainable polymers from recycled waste plastics [3] but also different types of waxes (natural or synthetic).

Bituminous binders may already contain waxes, present in the oils that gave rise to them, but their characteristics are different from PE waxes, and their effects are also diversified [4]. Usually, PE waxes offer good chemical and water resistance, excellent distribution and fluidity, high softening points, and better chemical stability than those resulting from oil refining [5].

As recently highlighted by Wijesekara et al. [6], who studied the use of chars (from postwaste plastic processing) in civil engineering, pyrolysis is a sustainable answer to convert some wastes into fuels (liquids and gases). They pointed out that pyrolysis "does not produce toxic soot" (which includes polycyclic aromatic hydrocarbons (PAH)), can offer an excellent calorific potential (around $40 \mathrm{MJ} \cdot \mathrm{kg}^{-1}$, comparable with conventional fuels), and the waxes can be used as "viscosity-reducing materials", especially in polymer-modified bitumen (PMB) (reducing heating costs in asphalt plants). In this regard, other authors found similar calorific values in waxes obtained in pyrolysis of HDPE (up to $45.4 \mathrm{MJ} \cdot \mathrm{kg}^{-1}$ ) [7] and waste polypropylene (about $43 \mathrm{MJ} \cdot \mathrm{kg}^{-1}$ ) [8]. As a curiosity, these last authors also used an orthogonal array (fractional factorial design) of the Taguchi method to optimize the wax production in their reactional system.

In the same direction, other recent reviews $[9,10]$ showed that transforming waste plastic into other products is a procedure with great potential and meets several of the mentioned U.N. Sustainable Development Goals (SDG). According to the estimates cited in [10], this conversion, through chemical recycling (where pyrolysis is included), could represent a saving of 3.5 billion barrels of oil per year. The Circular Plastics Alliance, created under a European Strategy for Plastics initiative (https:/ / ec.europa.eu/growth/industry/ strategy/industrial-alliances / circular-plastics-alliance_en, accessed on 23 February 2022), is already pushing for this processing, having committed to boosting "the EU market for recycled plastics to 10 million tonnes by 2025".

Indeed, one of the most sustainable and efficient processes for obtaining waxes $\left(>\mathrm{C}_{21}\right)$ is pyrolysis, which happens in the absence of oxygen (usually at a temperature between $350{ }^{\circ} \mathrm{C}$ and $900^{\circ} \mathrm{C}$ ). Another exciting advantage of the pyrolysis of plastic waste, particularly polyolefins (PO) (that constitute about $2 / 3$ of the overall plastic waste), is that it can be carried out in small units close to collection sites, thus avoiding their high transport costs [5]. However, Wu et al. [11] mentioned that the tertiary methods (chemical) of waste plastic recycling (which also include pyrolysis) usually have high costs.

In [12] can be found a very recent review of three pyrolysis processes of various plastic wastes (with the respective average production by a fraction): slow pyrolysis (usually performed at temperatures ranging from $350{ }^{\circ} \mathrm{C}$ to $550{ }^{\circ} \mathrm{C}$ and heating rates from 1 to $10{ }^{\circ} \mathrm{C} / \mathrm{min} \rightarrow$ produces more wax than oil), fast pyrolysis (generally at temperatures between $500{ }^{\circ} \mathrm{C}$ and $700^{\circ} \mathrm{C}$ with heating rates above $1000{ }^{\circ} \mathrm{C} / \mathrm{min} \rightarrow$ yields more liquid hydrocarbons), and flash pyrolysis (commonly above $700{ }^{\circ} \mathrm{C} \rightarrow$ releases more gas than 
liquids and more oil than in fast pyrolysis). As pointed out by Beghetto et al. [13], pyrolysis offers valuable products that are rich in hydrocarbons (liquid and wax-predominantly composed of alkanes and alkenes), and it is interesting for waste management and treatment activities [14]. It is also suitable to reprocess polymers that are difficult to recycle or even non-recyclable, including polypropylene (PP), polystyrene (PS) mixtures, and others. Consequently, different waxes that can be mixed with bituminous binders are available, namely those produced from waste plastic bags [15], PEX waste [6,16,17], PE waste [18], HDPE or low-density polyethylene (LDPE) [19], as well as Fischer-Tropsch wax (FTW) [20] (currently with some limitations because this process is essentially carried out using coal). Some authors [9] also highlighted the need to reduce biodiesels' percentage of waxes to avoid the filters' clog. Therefore, this removal can lead to its greater availability.

The processing of plastic waste through pyrolysis is also economically viable on an industrial scale, taking into account the value of its calorific potential, as confirmed by Ghodrat et al. [21]. In the profitability analysis of the pyrolysis suggested by those authors, a rate of return on investment (ROI) of $54 \%$ was achieved (assuming a feed rate of 40 tons/day and that the plastic waste would be collected, transported, and delivered to the processing site free of charge). However, it is recommended to take into account an extra cost related to the proper pre-sorting and elimination of waste that can give rise to unwanted compounds, as is the case for poly(vinyl chloride) (PVC), PET, or PU (their by-products include hydrochloric acid, benzoic acid, or hydrogen cyanide, respectively) [12,22,23].

Usually, the waxes are added (without other additives) to different binders in percentages ranging between $1 \%$ and $8 \%$ by wt. of bitumen. The primary purpose of its addition is to reduce the manufacturing and/or application temperatures on warm mix asphalt (WMA) [24-27] and to improve the coating of the aggregates and the workability of the mixture [27]. Many works have proven these benefits, namely, the one carried out in 2012 in Vancouver (Canada) [28] (where a mixing temperature reduction, from $160{ }^{\circ} \mathrm{C}$ to $121{ }^{\circ} \mathrm{C}$, was achieved). The literature has widely reported the benefits of blending this wax with binders for bituminous mixtures and pavements. Its advantages have been proven at the level of water sensitivity, stiffness modulus, fatigue cracking resistance, and rutting resistance [16,17], particularly when low traffic speed and adverse climatic conditions have significant impacts on pavements [15] or long-chain waxes (LCW) are used [18]. Other authors [29] concluded that if the wax content in a binder is high, its tendency to develop "bee-like" structures increases, which is especially beneficial for self-healing processes. However, these advantages are minimized by the impacts (environmental and economic) resulting from the production and transport of the incorporated additives [30].

Concerning mixing procedures, Desidery and Lanotte [18] warned of the consequences that the protocol followed can introduce on the performance of the binders, namely the ageing caused by the oxidation reactions and volatilization of light compounds during blending. They issued this warning after testing the effect on bitumen performance of two waxes (one from a waste PE and the other was a FTW), in a content of $1.5 \mathrm{wt} . \%$ of neat binder, at $180^{\circ} \mathrm{C}$, stirred at 500/1000 rpm and for up to $300 \mathrm{~min}$. Similar considerations were mentioned in other works that dealt with the mixing in bituminous binders (under different conditions) of several additives, namely nanoclays [31].

In summary, this paper describes the main materials used in this first part of the research (three unmodified bitumen, one PMB, the wax and some of their combinations), the respective samples' preparation, and the equipment and procedures followed in the tests performed. Finally, some results and the principal inferences, findings, and conclusions are aligned. These works are part of more comprehensive research, concluded in 2020 [32], the outcomes of which are not yet fully available due to the protection of reserved information.

The main aims of this work were the contribution to the reuse of waste resulting from a sustainable industry-chemical recycling (alternative feedstock or fuel production in the viewpoint of a Circular Economy of plastics [33]) and the improvements that the addition of this by-product can provide to specific bituminous binders (from a hard to a $\mathrm{PMB})$. The most important conclusions reached in this study were: the confirmation of 
the possibility of taking advantage of the "waste" from the processing of an end-of-life plastic (in a circular economy perspective) with benefits for the binders in which it is mixed; and that it is compatible with other modifiers (namely, SBS) and functional additives, substantially improving some of the rheological properties of the blends that include them.

\section{Materials and Methods}

\subsection{Materials}

\subsubsection{Wax Obtained from Plastic Waste}

The wax used in this research was obtained from an experimental system developed by co-authors Santos et al. [33-35], where the main objective was to produce light gaseous hydrocarbons and/or liquid fuels (gasoline in the most part). This reaction system (described in Section 2.2.1) is used for the thermal pyrolysis of polymers, namely for HDPE from plastic waste (for example, from crushed plastic waste obtained in the mechanical and biological treatments (MBT), landfills or source-separated packaging waste PE). Initially, various HDPE wastes were processed, and then, to have a basis for comparison and to ensure a higher reproducibility in the quality of the wax, fresh HDPE pellets were used. This material had $950 \mathrm{~kg} \cdot \mathrm{m}^{-3}$ (@ $23^{\circ} \mathrm{C}$ ) density, $27 \mathrm{MPa}$ tensile strength, $850 \%$ elongation, and melt indexes (@ $190^{\circ} \mathrm{C}$ ) of $0.23 \mathrm{~g} / 10 \mathrm{~min}\left(\mathrm{MFI}_{2.16}\right)$ and $20 \mathrm{~g} / 10 \mathrm{~min}\left(\mathrm{MFI}_{21.6}\right)$.

HDPE was selected as the source material as it decomposes solely into relatively simple hydrocarbons, including gaseous and liquid hydrocarbons, and, for the purpose of this work, waxes (no other toxic products are produced). As it has been previously studied by several researchers $[7,36-39]$, the characteristics of these waxes can be affected because of the reaction conditions (type and rate of gas used, temperature, pressure, duration, type of feedstock material, reactor type, and possible inclusion of catalysts [40]).

The developed composite binder that included this wax (in $2 \mathrm{wt} . \%$ ) was based on a PMB with SBS and finished with other functional additives. These additives allow the mitigation of less attractive trends (such as ageing) and improve the following binder properties: anti-oxidation, adhesiveness, rutting resistance, and elastic recovery. From now on, this blending is identified in this manuscript by the expression "PMB + wax".

\subsubsection{Binders}

In this study, four different binders were tested. The first one was a hard paving-grade bitumen (of class 10/20), two other binders were paving-grade bitumen (of classes 30/50, 50/70), and the fourth was a PMB of type 45/80-65 (from now on referred to as "PMB" only). Their main properties are listed in standards EN 13924-1 [41], NP EN 12591 [42], and NP EN 14023 [43], respectively, and are summarized in Tables 1 and 2. In addition, these tables also include the limits that must be respected when used in bituminous mixtures for different applications in Portugal (defined in the correspondent standards). In this paper, only results on consistency, thermal susceptibility, and viscosity are presented in Section 3 (but not for all binders or possible blends).

Table 1. Main requirements and standard limits for binders used in this study.

\begin{tabular}{|c|c|c|c|c|c|c|c|}
\hline Main Requirements & Parameters & $\begin{array}{c}\text { Test } \\
\text { Standards }\end{array}$ & Units & $10 / 20^{1}$ & $35 / 50^{2}$ & $50 / 70^{2}$ & $\begin{array}{l}\mathrm{PMB}^{3} \\
45 / 80-65\end{array}$ \\
\hline $\begin{array}{c}\text { Consistency: } \\
\text { At intermediate service temp. } \\
\text { At elevated service temp. } \\
\text { Cohesion: }\end{array}$ & $\begin{array}{c}\text { Penetration @ } 25^{\circ} \mathrm{C} \\
\text { Softening point, ring \& ball test }\end{array}$ & $\begin{array}{l}\text { EN } 1426 \\
\text { EN } 1427\end{array}$ & $\underset{{ }^{\circ} \mathrm{C}}{0.1 \mathrm{~mm}}$ & $\begin{array}{l}10-20 \\
58-78\end{array}$ & $\begin{array}{l}35-50 \\
50-58\end{array}$ & $\begin{array}{l}50-70 \\
46-54\end{array}$ & $\begin{array}{c}45-80 \\
\geq 65\end{array}$ \\
\hline $\begin{array}{c}\text { Low speed traction } \\
\text { Durability: }\end{array}$ & Force ductility @ $50 \mathrm{~mm} \cdot \mathrm{min}^{-1}$ & EN 13589/13587 & $\mathrm{J} \cdot \mathrm{cm}^{-2}$ & - & - & - & $\geq 3 @ 5^{\circ} \mathrm{C}$ \\
\hline Resistance to hardening & Change of mass, abs. value $( \pm)$ & - & $\%$ & - & $\leq 0.5$ & $\leq 0.5$ & $\leq 1$ \\
\hline $\begin{array}{l}\text { @ } 163^{\circ} \mathrm{C} \text {, after RTFOT } \\
\text { (EN 12607-1) }\end{array}$ & $\begin{array}{l}\text { Retained penetration @ } 25^{\circ} \mathrm{C} \\
\text { Increase in softening point }\end{array}$ & $\begin{array}{l}\text { EN } 1426 \\
\text { EN } 1427\end{array}$ & ${ }^{\%} \mathrm{C}$ & - & $\begin{array}{l}\geq 53 \\
\leq 8\end{array}$ & $\begin{array}{l}\geq 50 \\
\leq 9\end{array}$ & $\begin{array}{l}\geq 60 \\
\leq 10\end{array}$ \\
\hline $\begin{array}{c}\text { Recovery: } \\
\text { Strain recovery }\end{array}$ & Elastic recovery @ $25^{\circ} \mathrm{C}$ & EN 13398 & $\%$ & - & - & - & $\geq 70$ \\
\hline
\end{tabular}

As per: ${ }^{1}$ EN 13924-1:2015 [41]; ${ }^{2}$ NP EN 12591:2011 [42]; ${ }^{3}$ NP EN 14023:2013 [43]. 
Table 2. Main requirements and standard limits for binders used in this study-additional properties.

\begin{tabular}{|c|c|c|c|c|c|c|c|}
\hline $\begin{array}{c}\text { Main } \\
\text { Requirements }\end{array}$ & Parameters & $\begin{array}{c}\text { Test } \\
\text { Standards }\end{array}$ & Units & $10 / 20^{1}$ & $35 / 50^{2}$ & $50 / 70^{2}$ & $\begin{array}{c}\text { PMB }^{3} \\
45 / 80-65\end{array}$ \\
\hline $\begin{array}{l}\text { Thermal susceptibility } \\
\text { High temperature }\end{array}$ & $\begin{array}{l}\text { Penetration index (calculated) } \\
\text { Flash point }\end{array}$ & $\begin{array}{c}\text { EN } 12591 \\
\text { EN ISO } 2592\end{array}$ & ${ }^{\circ} \mathrm{C}$ & $\begin{array}{l}\geq-1.5 \\
\geq 245\end{array}$ & $\begin{array}{l}-1.5 /+0.7 \\
\geq 240\end{array}$ & $\begin{array}{l}-1.5 /+0.7 \\
\geq 230\end{array}$ & $-\overline{235}$ \\
\hline Storage stability & Difference in penetration or: & EN $13399 / 1426$ & $0.1 \mathrm{~mm}$ & - & $\begin{array}{c}2+40 \\
-\end{array}$ & - & $\begin{array}{l}<<9 \\
\leq 9\end{array}$ \\
\hline Solubility & $\begin{array}{l}\text { Difference in softening point } \\
\text { In toluene }\end{array}$ & $\begin{array}{c}\text { EN } 13399 / 1427 \\
\text { EN } 12592\end{array}$ & ${ }^{\circ} \mathrm{C}$ & $\begin{array}{l}- \\
-\end{array}$ & $>\overline{99.0}$ & $>\overline{9} 9.0$ & $\leq 5$ \\
\hline Sorubinty & Dynamic@60C & EN 12596 & $\mathrm{~Pa} \cdot \mathrm{S}$ & $\geq 700$ & $\geq 225$ & $\geq 145$ & - \\
\hline Viscosity & Kinematic@135 ${ }^{\circ} \mathrm{C}$ & EN 12595 & $\mathrm{~mm}^{2} \cdot \mathrm{s}^{-1}$ & $\geq 700$ & $\geq 370$ & $\geq 295$ & - \\
\hline
\end{tabular}

As per: ${ }^{1}$ EN 13924-1:2015 [41]; ${ }^{2}$ NP EN 12591:2011 [42]; ${ }^{3}$ NP EN 14023:2013 [43].

\subsection{Methods}

\subsubsection{Thermal Pyrolysis of HDPE in a Reactor/Separator Unit}

As mentioned before, pyrolysis has several advantages, namely environmental, arising from the fact that it takes place in an oxygen-free atmosphere; therefore, it does not produce dioxins and has no carbon monoxide and carbon dioxide emissions [44].

Different reactors can be used in pyrolysis, but the reaction system used in this research was the one developed at DL-DEQ-IST, depicted in Figure 1a, which also includes its schematic diagram (Figure 1b). In this thermal cracking system or thermal pyrolysis (which implies a relatively low cost, deviating from the trend referred to in [11]), the production of waxes represents the most significant fraction (from $40 \%$ to $92 \%$ [32]), with temperature and reaction time being two determining parameters in terms of the quantity available in each "batch". In general, this amount of wax is higher the lower the maximum temperature used; however, as the pyrolysis temperature increases, softer waxes tend to be produced. As mentioned in [34], for temperatures in the range of $430-500{ }^{\circ} \mathrm{C}$, the waxes obtained in this system can represent $40-80 \%$ of the initial mass of the plastic waste. So, as the properties and yield of the wax produced are dependent on the pyrolysis conditions, several pyrolysis temperatures were tested, and to maximize the waxes' production, a set-point of $470{ }^{\circ} \mathrm{C}$ was chosen in this research (the temperature profile in the reactor had an average of $405^{\circ} \mathrm{C}$, for $90 \mathrm{~min}$ ). The waxes produced under these conditions provided the best results in a preliminary study to evaluate their influence on the mixture with several types of bitumen. In this case, the mean percentage obtained in the wax production was $\approx 92 \%$, and the liquid fraction (oil) was around $4 \%$.

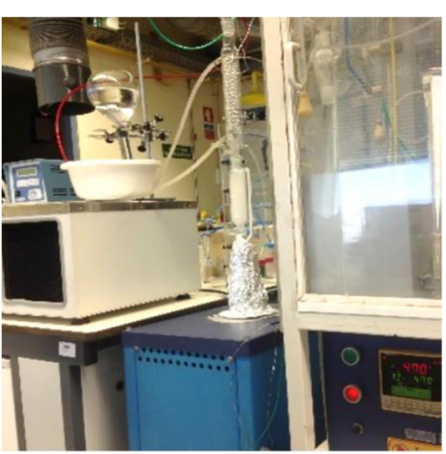

(a)

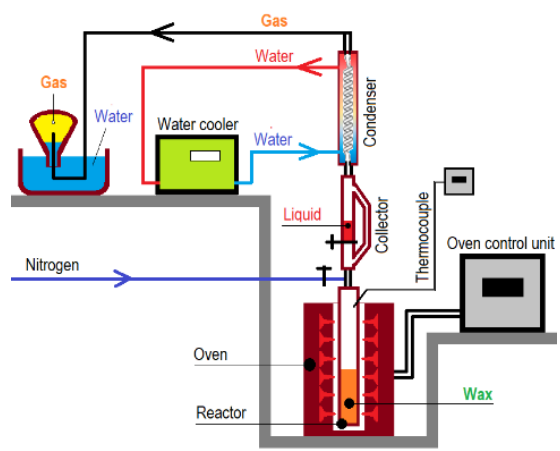

(b)

Figure 1. DL-DEQ-IST thermal pyrolysis: (a) reactional system; (b) schematic diagram.

\subsubsection{Thermal Analysis for Characterization of Wax and Binders}

Several standards can be followed in analysing different plastic/wax samples by thermogravimetry: ASTM E1131, ASTM E1269, ASTM E2550, EN ISO 11357 [45], and others. The evaluation of enthalpies, internal transition energy, and thermal capacity, including degradation temperature, was conducted in a Differential Scanning Calorimeter (DSC) by a dynamic or non-isothermal method (in which the equipment is operated with a continuous temperature sweep) at a constant rate of $25^{\circ} \mathrm{C} \cdot \mathrm{min}^{-1}$. The equipment used to obtain the thermogravimetry of wax and binders was a PerkinElmer-STA6000 (Company, 
Waltham, MA, USA). During the equipment operation, the nitrogen $\left(\mathrm{N}_{2}\right)$ flow was equal to $20 \mathrm{~mL} \cdot \mathrm{min}^{-1}$, and alumina crucibles were used.

\subsubsection{Spectroscopic Analysis of Wax and Binders}

To better assess some information that can be used to predict the physical and chemical properties of binders arising from differences in energy absorbed by molecules and their infrared radiation [46], infrared spectroscopy was also used [47-50]. It is based on evaluating the properties of atoms and molecules in absorbing or transmitting electromagnetic energy in the mid-infrared region (from $400 \mathrm{~cm}^{-1}$ to $4000 \mathrm{~cm}^{-1}$ ), using a Fourier-Transform Infrared (FTIR) spectrometer.

The wax and binder samples were previously mixed with Potassium Bromide $(\mathrm{KBr}$, $\mathrm{m}=119 \mathrm{~g} \cdot \mathrm{mol}^{-1}$ ), and the FTIR used was a Bruker-Alpha (Ettlingen, Germany). The resolution was $4 \mathrm{~cm}^{-1}$, and the number of scans was equal to 16 . Three fundamental parameters of the spectral bands were evaluated: the intensity level of the peaks (weak, medium, strong), the type of shape (wide, narrow), and their positions (wavenumber, $\left.\bar{v}\left(\mathrm{~cm}^{-1}\right)\right)$.

\subsubsection{Characterization of Bituminous Binders}

The consistency at an intermediate service temperature of binders (needle penetration, P) was evaluated following the NP EN 1426 [51] standard, at a temperature of $25^{\circ} \mathrm{C}$, under the action of a load of $100 \mathrm{~g}$ applied for $5 \mathrm{~s}$. The test equipment used was a UTEST-UTAS0120 (Ankara, Turkey).

According to standard NP EN 1427 [52], consistency at an elevated service temperature of binders was evaluated through the softening point ring and ball method (obtaining the temperature, $t_{R a B}$, at which $P=800 \times 0.1 \mathrm{~mm}$ ), in a UTEST-UTAS-0130 (Ankara, Turkey) equipment. This test method and the penetration test are not sufficiently representative of PMB's properties.

The penetration index $\left(I_{p}\right)$ can be calculated to measure the temperature susceptibility of binders and is obtained from the penetration values at two different temperatures or from the penetration at $25^{\circ} \mathrm{C}$ and softening point. Equation (1) [53] (developed by Pfeiffer and Van Dormal) is used in the latter case.

$$
I_{p}=\frac{20 \times t_{R a B}+500 \times \log P-1951.55}{t_{R a B}-50 \times \log P+120.15}
$$

where $t_{R a B}$ is the softening point $\left({ }^{\circ} \mathrm{C}\right)$ and $\log P$ is the logarithm (base 10) of the penetration @ $25{ }^{\circ} \mathrm{C}(0.1 \mathrm{~mm})$. A bitumen with $P=200 \times 0.1 \mathrm{~mm}$ (at $\left.25^{\circ} \mathrm{C}\right)$ and $t_{R a B}=40{ }^{\circ} \mathrm{C}$ has an $I_{p}$ equal to zero. Naturally, this index is also not representative of the PMB's properties due to the uncertainty of the variables required in Equation (1). However, the $I_{p}$ for PMB was established to have an indication of the thermal susceptibility of this binder and to be compared with the limits specified in the standards (Tables 1 and 2).

The steady shear viscosity or dynamic viscosity $(\eta)$ can be obtained by using a rotating spindle apparatus, according to the European standard EN 13302 [54]. A correct indication of the measurement geometry for cylindrical spindles is given in Figure 2c. The equipment used was a Selecta-ST-2020R rotational viscosimeter (Barcelona, Spain), Figure 2b. The previous wax $\rightarrow$ bitumen mixing was performed using a suitable high-shear mixer, Figure 2a, at a temperature of $\approx 150{ }^{\circ} \mathrm{C}$, with speeds of $800 / 1250 \mathrm{rpm}$ and a duration of just $\approx 10 \mathrm{~min}$ (in order to minimize the ageing effects).

Using a Dynamic Shear Rheometer (DSR), the bituminous binders' complex shear modulus $\left(G^{*}\right)$ and phase angle $(\delta)$ were obtained, over a range of test temperatures at a fixed frequency, according to the European standard EN 14770 [55]. This test was carried out in the region of linear viscoelastic behaviour of the binder. In [56] can be found several correlations between dynamic test parameters for binders (on a DSR, using a sinusoidal oscillatory mode) and permanent deformation behaviour of bituminous mixtures (for example, in wheel-tracking tests, WTT). The equipment used (Bohlin Instruments-DSR II10 
INT, Texas City, TX, USA.) and the procedure followed are presented in Figure 3. During the tests, the binder samples were conditioned in water (with controlled temperature).

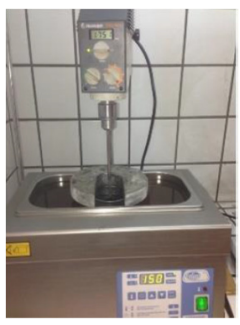

(a)

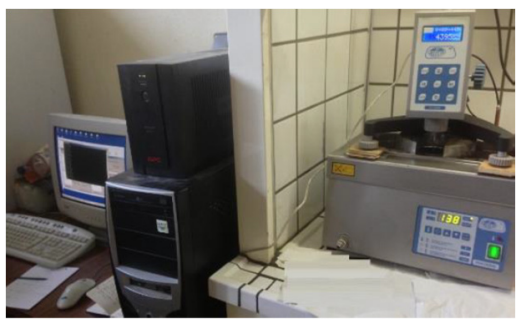

(b)

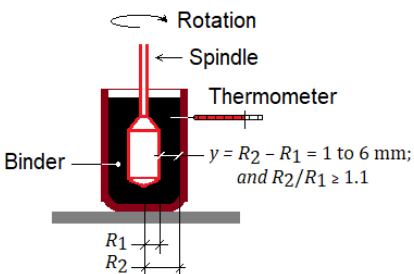

(c)

Figure 2. Steady-shear rheology: (a) wax/binder mixture; (b) viscometer; (c) operating mode.

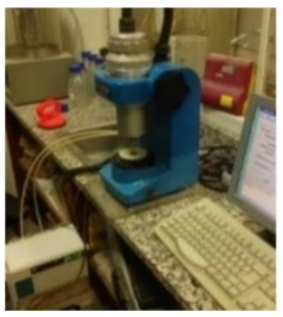

(a)

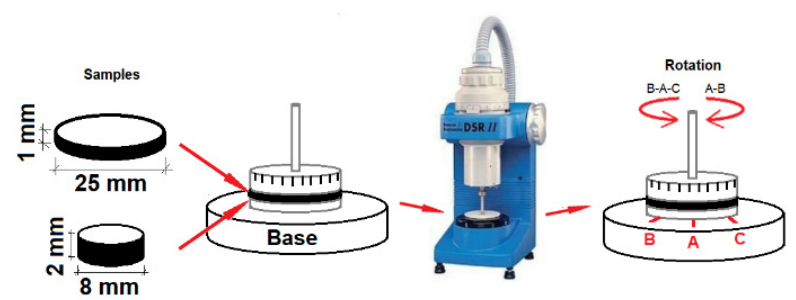

(b)

Figure 3. Dynamic rheology: (a) dynamic shear rheometer; (b) its operating mode.

The results achieved in each of the tests described in this Section 2.2 and their discussion and comparison with some results of similar research published by other authors, are presented in Section 3.

\section{Results and Discussion}

\subsection{Thermogravimetric Analysis (DSC)}

Figure 4 shows the normalized results for the wax formed in pyrolysis, under the conditions described in Section 2.2.1, after testing on the DSC identified in Section 2.2.2.

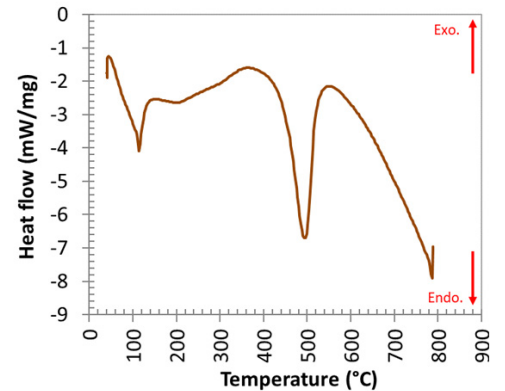

(a)

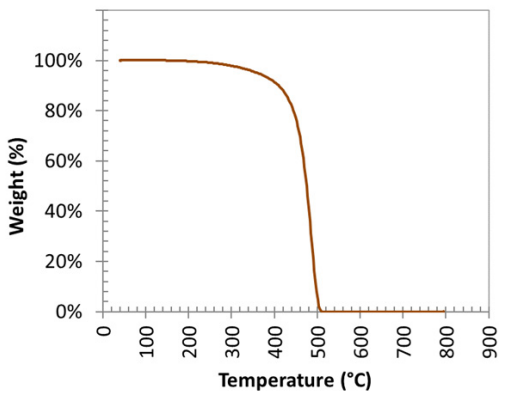

(b)

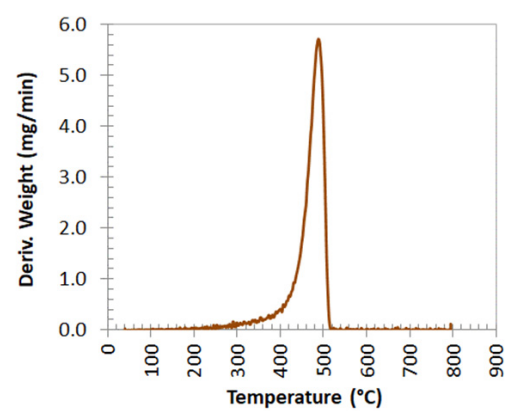

(c)

Figure 4. Wax-thermogravimetric analysis (normalized): (a) heat flow; (b) weight loss; (c) derivative weight.

The heat flow curve showed two endothermic peaks: the first band, which appeared at intermediate temperature $\left(\approx 114^{\circ} \mathrm{C}\right)$, was attributed to wax melting, and the second band (around $500{ }^{\circ} \mathrm{C}$ ) indicated that a degradation step occurred when the conversion took place (the thermal degradation initiation temperature, $\mathrm{T}_{\text {onset }}$, is about $450{ }^{\circ} \mathrm{C}$ ). The melting temperature peak (at $\approx 114{ }^{\circ} \mathrm{C}$ ) was higher than the range pointed out in [7] $\left(70-80{ }^{\circ} \mathrm{C}\right)$ for waxes obtained from HDPE at $500^{\circ} \mathrm{C}$ or even for FT waxes $\left(\approx 100{ }^{\circ} \mathrm{C}\right)$ [25], but it was smaller than the ones published by Motawie et al. [38] $\left(129^{\circ} \mathrm{C}\right)$ and Rodríguez-Luna et al. [57] $\left(128.5^{\circ} \mathrm{C}\right)$. So, when this wax was added to bitumen, the manufacturing temperature of 
the bituminous mixture could be substantially lower when compared to that specified for traditional binders (35/50 and PMB), generally above $160^{\circ} \mathrm{C}$. In addition, its residue (char) after degradation (weight curve) was almost nil.

In Figure 5, the normalized results for three studied binders are shown, measured on the same DSC test equipment identified in Section 2.2.2 (under conditions described in Section 2.2.1).

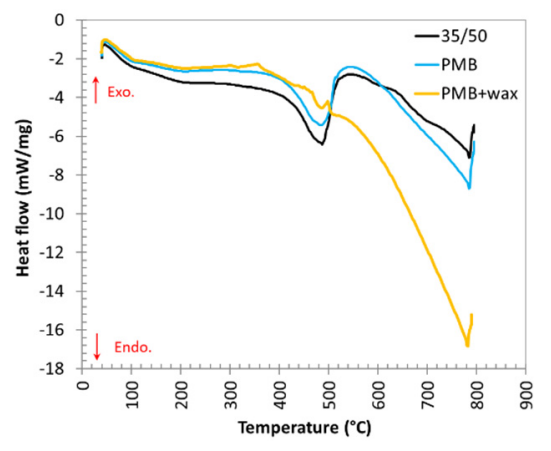

(a)

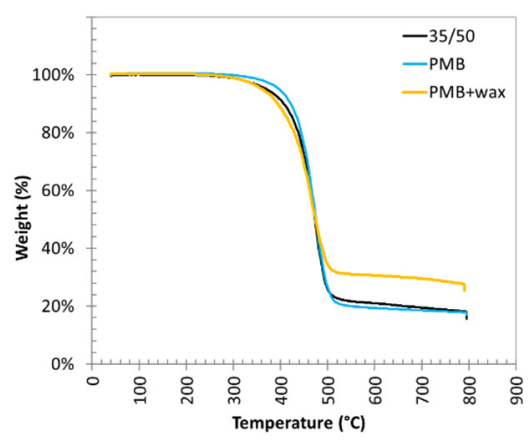

(b)

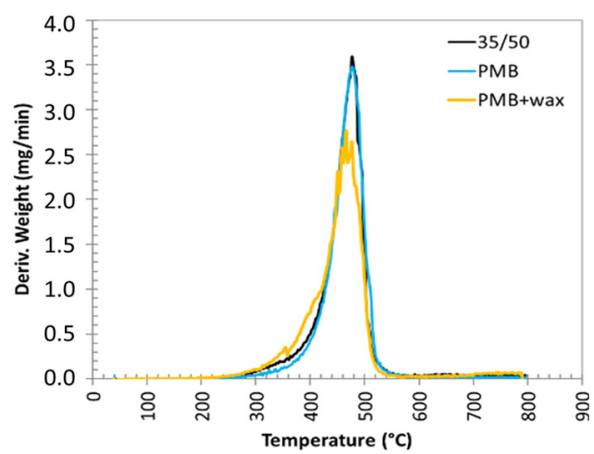

(c)

Figure 5. Binders—-thermogravimetric analysis (normalized results): (a) heat flow; (b) weight; (c) derivative weight.

In these thermograms, only minor differences could be observed in the melting behaviour of all samples, while the enthalpy energy in degradation (for temperatures ranging between $450{ }^{\circ} \mathrm{C}$ and $500{ }^{\circ} \mathrm{C}$ ) had substantial dissimilarities. These last peaks, where the maximum mass loss occurred, were related to the volatilization of hydrocarbons. The differences observed in the heat flow and residue of the PMB + wax, compared to PMB, were also partially due to the functional additives included. In the case of PMB + wax, the difference in residue at $800{ }^{\circ} \mathrm{C}$ could also have been affected by the shear rate and the mixing time used (conditions that affect the char content, as proved by Kaya et al. [58] for SBS/binder blends).

\subsection{Infra-Red Spectroscopy (FTIR)}

Figure 6 shows the FTIR spectrum of the wax produced in the reactional system presented in Section 2.2.1, under the conditions described there (after normalization).

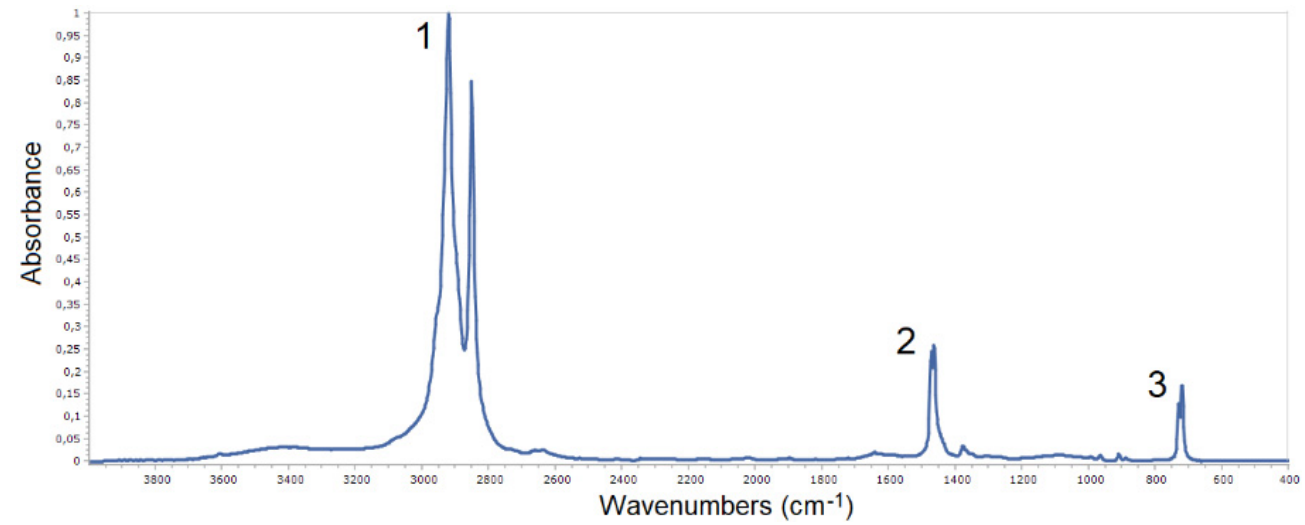

Figure 6. Wax-FTIR spectrum (normalized).

The main peaks observed in this spectrum are described in more detail in Table 3, which includes the Full Width at Half Maximum measure (FWHM) for each spectral band. 
Table 3. Characteristics of the most significant spectral bands of the wax (normalized peaks).

\begin{tabular}{cccc}
\hline Parameters & Peak 1 & Peak 2 & Peak 3 \\
\hline Absorbance & 1.00 & 0.26 & 0.17 \\
FWHM $\left(\mathrm{cm}^{-1}\right)^{1}$ & 37.26 & 20.35 & 18.31 \\
Wavenumber $\left(\mathrm{cm}^{-1}\right)$ & 2919.30 & 1463.80 & 719.88 \\
\hline
\end{tabular}

${ }^{1}$ FWHM-Full Width at Half Maximum.

On the one hand, at peak 1 (reference band for normalization), it was possible to identify the band corresponding to the vibrational mode of the $\mathrm{C}-\mathrm{H}$ bonds (symmetric and asymmetric stretching), which were characteristic of the $\mathrm{CH}_{2}$ functional group. On the other hand, peak 2 showed the $\mathrm{C}-\mathrm{H}$ scissoring and symmetrical bending vibrational modes of the $\mathrm{CH}_{2}$ and $\mathrm{CH}_{3}$ functional groups. Finally, peak 3 corresponded to the $\mathrm{C}-\mathrm{H}$ bending vibrational mode of the $\mathrm{CH}=\mathrm{C}$ functional groups. In summary, these bonds were similar to those originated by the same functional groups in other comparable waxes [7], although with a more pronounced olefinic nature (due to the formation of $\mathrm{C}=\mathrm{C}$ functional groups during the pyrolysis process), confirmed by the existence of small bands positioned between $900 \mathrm{~cm}^{-1}$ and $1000 \mathrm{~cm}^{-1}$ (assigned to the $\mathrm{R}-\mathrm{CH}=\mathrm{CH}_{2}$ functional group).

Figure 7 shows the spectra for three of the studied binders, with the most significant normalized peaks in each curve being identified in Figure $7 \mathrm{~b}$.

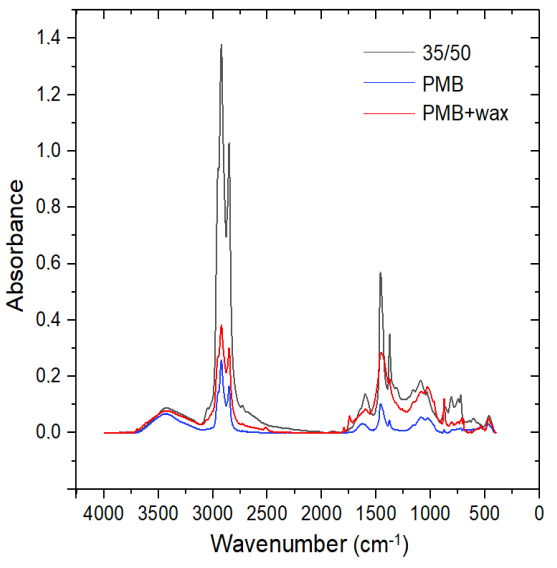

(a)

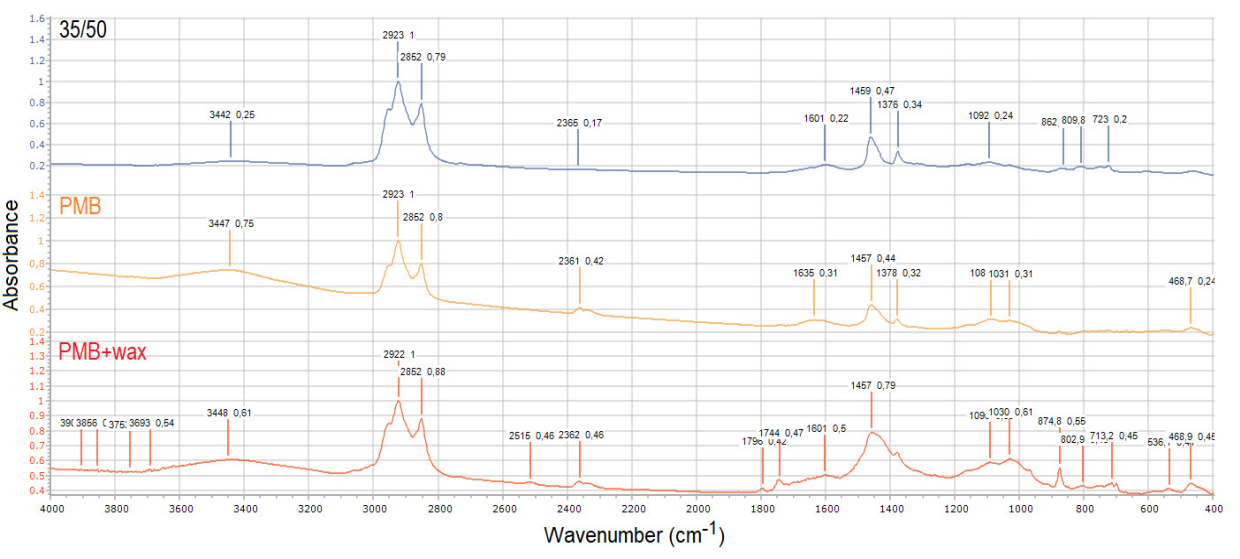

(b)

Figure 7. Binders-FTIR spectra (35/50, PMB, PMB + wax): (a) overlaid on the graph; (b) stack spectra (normalized).

These FTIR spectra of the binder samples showed that the principal peaks corresponded to the asymmetric stretching vibration of the aliphatic group and were positioned, on all binders, at wavenumber $2922 / 3 \mathrm{~cm}^{-1}$. The secondary peaks were identified around $1457 / 9 \mathrm{~cm}^{-1}$ and corresponded to asymmetric bending vibrations of the same aliphatic group (Methyl). Other peaks could also be identified at $1376 / 8 \mathrm{~cm}^{-1}$, corresponding to symmetric bending bond vibration (branched aliphatic group-Methylene).

On the PMB + wax binder, the small visible peaks at wavenumbers $1744 \mathrm{~cm}^{-1}$ and $1030 \mathrm{~cm}^{-1}$ could also be related to oxidized products: the carbonyl $\left(\mathrm{C}=\mathrm{O}\left(1690-1740 \mathrm{~cm}^{-1}\right)\right)$ and sulfoxide $\left(\mathrm{S}=\mathrm{O}\left(1030-1055 \mathrm{~cm}^{-1}\right)\right.$ ) groups, respectively. The presence of these compounds may also be associated with the slight ageing that took place when mixing the wax with the PMB. However, these peaks would be greater if this composition did not include an anti-oxidant. In fact, as highlighted by Tauste et al. [59], oxidation is the leading cause of binder ageing, as it gives rise to irreversible chemical changes; therefore, it is essential to minimize this phenomenon as much as possible. 


\subsection{Penetration (P), Softening Point $\left(t_{R a B}\right)$, and Thermal Susceptibility $\left(I_{p}\right)$}

Figure 8 presents the results achieved for penetration, softening point, and thermal susceptibility (thermal susceptibility). As already pointed out, for PMB, the values reflected some uncertainties due to the characteristics of the test methods and the heterogeneities in the dispersion of polymers. In the case of PMB + wax, because of the introduction of the functional additives already mentioned, it was not the case that the penetration grade was higher (and the softening point was lower) than for PMB. This disposition was in line with what is suggested by several authors, such as those mentioned in [3], who recommended that additives to modify bitumen must have, among other attributes, the ability to reduce its thermal susceptibility.

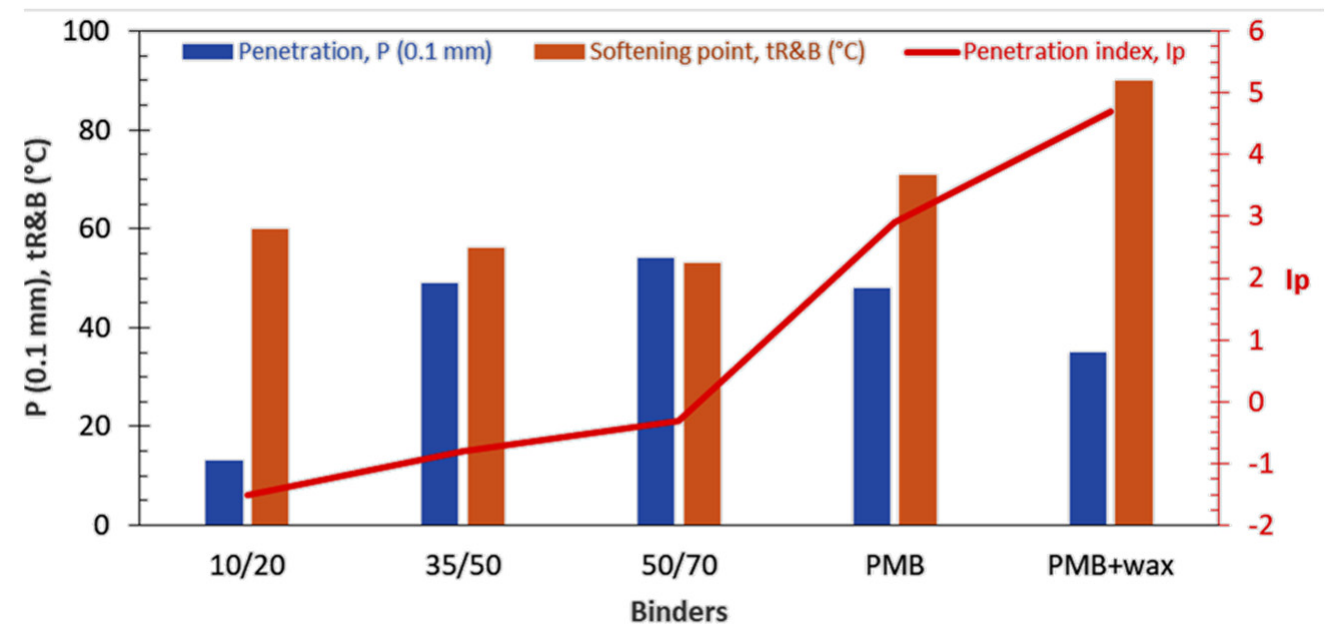

Figure 8. Consistency and thermal susceptibility of the evaluated binders.

The PMB + wax led to a reduction in penetration of $13 \times 0.1 \mathrm{~mm}$ at $25{ }^{\circ} \mathrm{C}$ and an increase in the softening point at $18{ }^{\circ} \mathrm{C}$. Concerning the behaviour at high service temperatures, it was verified that the $I_{p}$ of the PMB + wax was the highest (much better than the one mentioned in [17]) and, therefore, its thermal susceptibility was the lowest. This tendency was also in line with the one cited in [17] (penetration decreased and softening point increased in PMB with waxes), where the authors presented the effects of adding a recycled pyrolytic cross-linked polyethylene wax (RPPW) and an FTW on a PMB with SBS, as shown in Table 4.

Table 4. Consistency and thermal susceptibility of different PMB.

\begin{tabular}{|c|c|c|c|c|c|c|c|}
\hline Requirements & Parameters & Units & РМB & $\begin{array}{r}\text { PMB } \\
+\operatorname{wax}^{1}\end{array}$ & $\mathrm{PMB}^{2}$ & $\begin{array}{c}\text { PMB }^{3} \\
+ \text { RPPW }\end{array}$ & $\begin{array}{l}\text { PMB }^{4} \\
+ \text { FTW }\end{array}$ \\
\hline $\begin{array}{c}\text { Consistency: } \\
\text { At intermediate service temp. } \\
\text { At elevated service temp. } \\
\text { Additional property: } \\
\text { Thermal susceptibility }\end{array}$ & $\begin{array}{l}\text { Penetration @ } 25^{\circ} \mathrm{C}, P \\
\text { Softening point, } t_{R a B} \\
\text { Penetration index } I_{n}\end{array}$ & $\underset{{ }^{\circ} \mathrm{C}}{0.1 \mathrm{~mm}}$ & $\begin{array}{l}48 \\
71\end{array}$ & $\begin{array}{l}35 \\
90\end{array}$ & $\begin{array}{r}69.2 \\
67.7 \\
-0.245\end{array}$ & $\begin{array}{l}65.1 \\
89.1\end{array}$ & $\begin{array}{l}46.5 \\
94.7\end{array}$ \\
\hline
\end{tabular}

${ }^{1}$ It also includes functional additives; ${ }^{2}$ in $[17] ;{ }^{3}$ in [17] for $3 \%$ of RPPW; ${ }^{4}$ in [17] for $3 \%$ of FTW (FT wax).

\subsection{Dynamic Viscosity $(\eta)$}

The dynamic viscosities $(\eta)$ of the unmodified binders $(10 / 20,35 / 50$, and $50 / 70)$ achieved in the rotational viscometer identified in Section 2.2.4 are shown in Figure 9. This table also includes the results obtained from mixing wax into two types of paving-grade bitumen (10/20 and 35/50, which are referenced as " $10 / 20+$ wax" and "35/50 + wax"). 


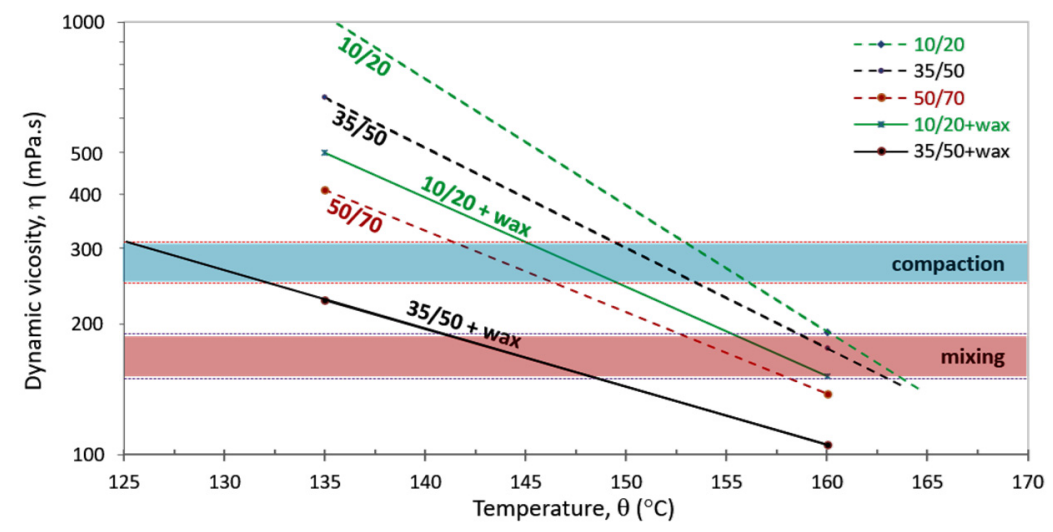

Figure 9. Dynamic viscosity of unmodified binders, with and without wax.

Through the dynamic viscosity-temperature profiles evaluated in the viscometer, it was possible to verify that, on average, the addition of a pure wax ( $2 \%$ by wt. of binder) to the $10 / 20$ bitumen reduced the viscosity, for example, by about $200 \mathrm{mPa} \cdot \mathrm{s}$ and more than $250 \mathrm{mPa} \cdot \mathrm{s}$ for the $35 / 50$ bitumen (at $\approx 145^{\circ} \mathrm{C}$ ). These reductions are essential for manufacturing and applying bituminous mixtures that incorporate this additive. As with other wax from XLPE [6], this wax also has a high potential to be used in PMB with SBS as a viscosity-reducing additive. Such reductions are even superior to those promoted by the waxes used by Shang et al. [17], blended with a $70 \times 0.1 \mathrm{~mm}$ penetration-grade bitumen and evaluated at $135^{\circ} \mathrm{C}$ : when $3 \%$ of RPPW was added, the viscosity was reduced by $77 \mathrm{mPa} \cdot \mathrm{s}$, while with $3 \% \mathrm{FTW}$, it was lowered by only $18 \mathrm{mPa} \cdot \mathrm{s}$.

Table 5 shows different temperatures recommended for hot mix asphalt (HMA) made with the traditional 35/50 neat bitumen and incorporating pure wax (without functional additives). In this case, dynamic viscosity can be considered approximately equal to the kinematics $(\mu)$, the one referred to in the European standard [42] (the difference is only a function of the specific weight of the binder, slightly higher than $\left.1 \mathrm{~g} \cdot \mathrm{cm}^{-3}\right)$. These results confirm the influence of this wax on the viscosity of the most used bituminous binder in the Iberian Peninsula, which can also contribute to a reduction in energy costs in manufacturing and applying HMA/WMA, especially at the current time of high prices.

Table 5. Recommended viscosities ${ }^{1}$ and temperatures for $35 / 50$ and $35 / 50+$ wax binders.

\begin{tabular}{|c|c|c|c|c|c|c|c|}
\hline \multirow{3}{*}{ Phase } & \multirow{3}{*}{$\begin{array}{l}\text { Kinematic } \\
\text { Viscosity }^{1} \\
\left(\mathrm{~mm}^{2} \cdot \mathbf{s}^{-1}\right)\end{array}$} & \multicolumn{4}{|c|}{ Temperatures $\left({ }^{\circ} \mathrm{C}\right)^{2}$} & \multirow{2}{*}{\multicolumn{2}{|c|}{$\begin{array}{l}\text { Differences }\left({ }^{\circ} \mathrm{C}\right) \\
\text { from } 35 / 50 \text { to } 35 / 50+\text { wax }\end{array}$}} \\
\hline & & \multicolumn{2}{|c|}{$35 / 50$} & \multicolumn{2}{|c|}{$35 / 50+$ wax } & & \\
\hline & & Start & Finish & Start & Finish & Start & Finish \\
\hline Mixing & $170 \pm 20$ & 158 & 163 & 141 & 148 & -17 & -15 \\
\hline Compaction & $280 \pm 30$ & 149 & 153 & 125 & 132 & -24 & -21 \\
\hline
\end{tabular}

${ }^{1}$ As per NP EN 12591 [42]; ${ }^{2}$ according to the recommended limits for kinematic viscosities.

It was also possible to calculate other dynamic viscosity (complex) values from the test results in the DSR, respecting the European standard EN 14770 [55]. This calculation was a function of the complex shear modulus $(\mathrm{G} *)$, revealed in Section 3.5. This complex dynamic viscosity, $\eta^{*}(\mathrm{~Pa} \cdot \mathrm{s})$, was obtained in each of 12 to 15 iterations (for each test temperature), dividing $\mathrm{G}^{*}(\mathrm{~Pa})$ by the angular velocity, $\omega\left(\mathrm{rad} \cdot \mathrm{s}^{-1}\right)$, for a strain amplitude $(\gamma)$ ranging between $\approx 2 \%$ (1st iteration) and $\approx 30 \%$ (15th iteration).

Figure 10 shows the average results calculated in this way for three binders (two traditional bitumens (35/50; $\mathrm{PMB}$ ), and the $\mathrm{PMB}+$ wax) at each test temperature (for $\omega \approx$ $1.6 \mathrm{~Hz} \approx 10 \mathrm{rad} \cdot \mathrm{s}^{-1}$ and test temperatures in the range of $\left.46-88^{\circ} \mathrm{C}\right)$. The $\eta^{*}$ of $\mathrm{PMB}+$ wax (which also includes functional additives) at temperatures below $90^{\circ} \mathrm{C}$ (essential for their mechanical performance in service), was the largest of the three binders. The functional additives added induced an appropriate contribution to the permanent deformation resistance without impairing the fatigue strength of the bituminous mixtures (which was later evaluated in flexion-tensile tests on four-point bending equipment-4PB) $[32,60]$. 


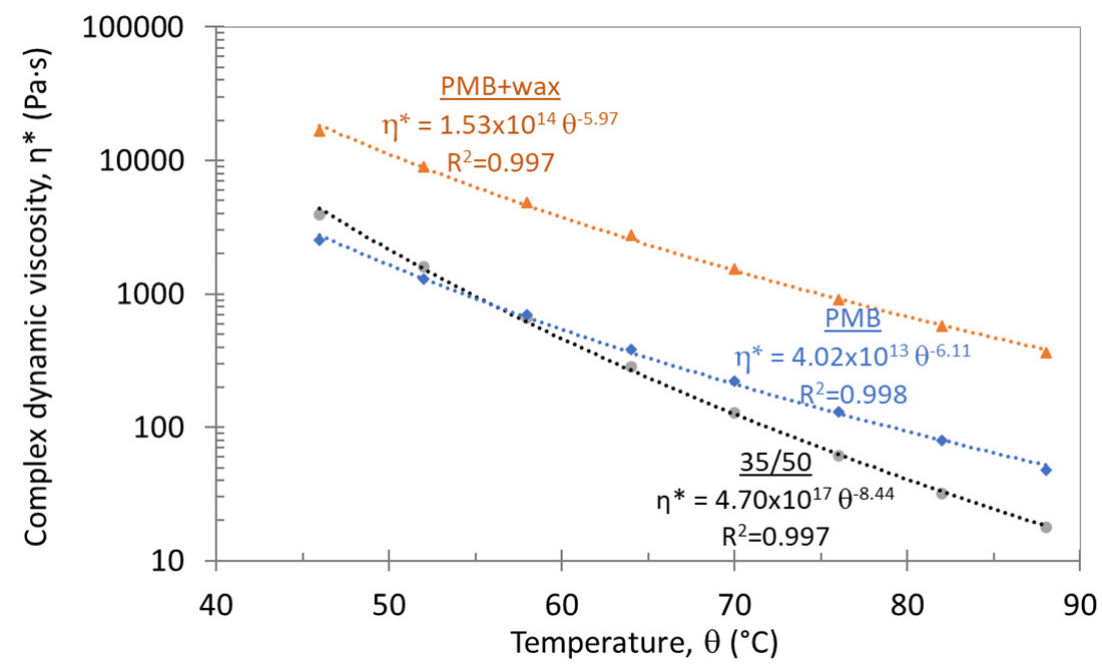

Figure 10. Complex dynamic viscosity $\left(\eta^{*}\right)$ of three bituminous binders.

\subsection{Complex Shear Modulus $\left(G^{*}\right)$ and Phase Angle $(\delta)$}

Figure 11 shows the evolution of complex shear modulus $\left(\mathrm{G}^{*}\right)$ and phase angle $(\delta)$ as a function of temperature $(\theta)$, obtained in the DSR identified in Section 2.2.4 (@ $\omega \approx 1.6 \mathrm{~Hz} \approx$ $\left.10 \mathrm{rad} \cdot \mathrm{s}^{-1}\right)$. The samples were $25 \mathrm{~mm}$ in diameter, $1 \mathrm{~mm}$ in thickness, and were moulded with the same three bituminous binders (35/50, PMB, and PMB + wax).

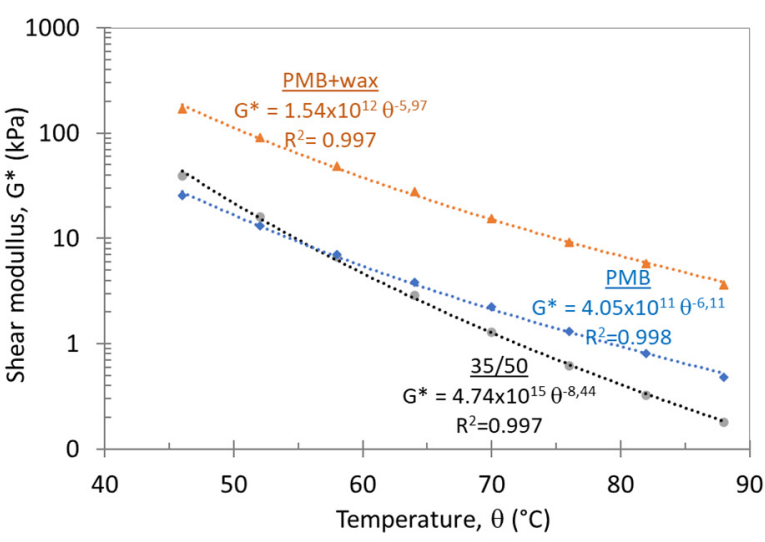

(a)

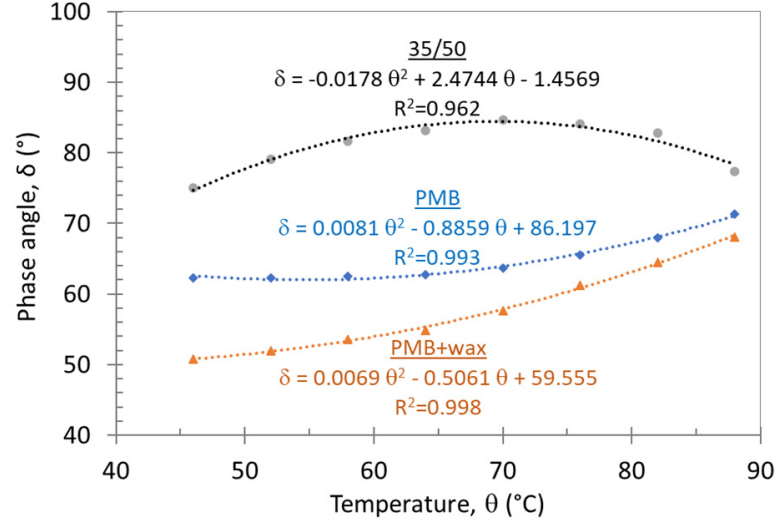

(b)

Figure 11. Rheological properties of bituminous binders: (a) complex shear modulus $\left(\mathrm{G}^{*}\right)$; (b) phase angle $(\delta)$.

It was observed that thend line of shear modulus versus temperature of $\mathrm{PMB}+$ wax was the one that presented the lower exponent (in absolute value). Furthermore, the phase angles measured in this binder also showed the lowest values at all temperatures. Thus, in this case, it could be inferred that PMB + wax respects the objective of achieving high values of $G^{*}$ and low values of $d$ to have better rutting resistance. A similar conclusion was already achieved by Tasdemir [61] after testing FT and PE waxes mixed in two soft binders (50/70 and 160/220). This researcher stated that when the modification is conducted correctly, incorporating these waxes improves the performance of the bituminous mixtures at high temperatures.

Table 6 shows a comparison between the results of mixing three different waxes in two PMB (the one studied in this research (PMB + wax) and two others tested by Shang et al. [17] - RPPW and FTW). The evaluated parameters, the rutting resistance $\left(G^{*} / \sin d\right.$, at $60^{\circ} \mathrm{C}$ ) and the upper limit temperature (when $G^{*} / \sin d=1 \mathrm{kPa}$ or $\log \left(G^{*} / \sin \mathrm{d}\right.$ ) = 0 , with $\mathrm{d}$ being in radians), were defined according to SHRP specifications [62]. 
Table 6. Effects of three different waxes on the rutting resistance parameters of two PMB.

\begin{tabular}{|c|c|c|c|c|c|}
\hline $\begin{array}{c}\text { Parameters } \\
\text { (SHRP Specifications) }\end{array}$ & PMB $^{1}$ & $\begin{aligned} & \text { PMB } \\
+ & \text { Wax } 1,2\end{aligned}$ & $\mathrm{PMB}^{3}$ & $\begin{aligned} & \text { PMB } \\
+ & \text { RPPW }^{4}\end{aligned}$ & $\begin{aligned} & \text { PMB } \\
+ & \text { FTW }^{4}\end{aligned}$ \\
\hline $\mathrm{G}^{*} / \sin \delta, @ 60^{\circ} \mathrm{C}(\mathrm{kPa})$ & 6.09 & 46.23 & 1.10 & 1.11 & 8.90 \\
\hline Upper limit temperature $\left({ }^{\circ} \mathrm{C}\right)$ & 80.3 & 110.8 & 61.0 & 61.2 & $>100$ \\
\hline
\end{tabular}

${ }^{1}$ From this research; ${ }^{2}$ plus functional additives; ${ }^{3}$ in [17]; ${ }^{4}$ in [17] for $3 \%$ of RPPW or FTW.

It was possible to confirm that adding the developed wax blend (PMB + wax) and FTW (a commercial FT wax for WMA) makes both PMB less sensitive to rutting and promotes an increase in the upper limit temperature, while the RPPW (obtained from the pyrolysis of "recycled cross-linked polyethylene", previously chipped) favours a slight variation. However, as mentioned by Radhakrishnan et al. [62], the use of the SHRP parameter $\left(\mathrm{G}^{*} / \sin \mathrm{d}\right)$ is under scrutiny as it will not be the best way to assess the rutting resistance of binders, particularly at higher temperatures. For this reason, the protocol known as multiple-stress creep recovery (MSCR) has been applied more since 2011. In this procedure, the $\mathrm{J}_{\mathrm{nr}}$ and \%R parameters (non-recoverable creep compliance and recovery percentage, respectively) are evaluated, using the EN 16659 [63] or AASHTO T350 standards, which give better indications about the performance of binders at high temperatures [28,32].

\subsection{Synthesis of the Principal Inferences and Findings}

In general terms, from the assessment of the works and tests carried out, it was possible to frame the following inferences: the HDPE waxes can be obtained in a relatively simple reaction system, with a very high yield, and one of the remaining products is a valuable fuel that can be used on-site to provide the energy required for the process (thus avoiding the consumption of energy generated by other sources); they change the viscosity of the binders, favouring a reduction in the handling temperature of binders/mastics/bituminous mixtures (when finished with functional additives); and contribute to the chemical recycling of plastics, as well as to the fulfilment of some of the goals defined in the U.N. 2030 Agenda.

Other findings can be mentioned, namely that the test results strongly depended on the analysed samples, their representativeness, dimensions, heterogeneities, and measurement fidelity (test precision-repeatability and reproducibility). It was also possible to confirm that the advanced characterization of binders (e.g., with comprehensive rheological tests) is more suitable to help find compositions that present added value in more differentiating parameters. Traditional and standardized assessments are usually not enough to distinguish complex binders.

In addition, some trends that could be of relevance for future developments in these sustainable production processes were noticeable. For example, as commented by Nanda et Berruti in a recent review [39], the future for plastic waste can go through co-processing technologies, such as co-pyrolysis, including its blending with biomass. In the words of those authors, such technologies have "tremendous environmental and economic advantages". Other researchers also pointed to similar co-processing technology [64] (pyrolysis of the mixture of HDPE with wood) as a promising method or referred to the usefulness of using renewable and low-cost catalysts, such as those derived from lignocellulosic waste [65].

Further directions may also be taken in future research, namely evaluating the influence of mixing these waxes with nanoclays [30,66], aged bitumen from reclaimed asphalt pavement (RAP) $[67,68]$, or polymeric capsules containing rejuvenators to promote selfhealing [69]. Likewise, it will be helpful to study the long-term performance of different bituminous mixtures with a binder such as the PMB + wax presented in this study and evaluate their recyclability potential [70], including the advanced characterization after an accelerated ageing procedure [71,72]. This evaluation can be performed using, among other test methods, the MSCR protocol following, for example, the European standard EN 16659 -adopting two stress levels $(0.1 \mathrm{kPa} \wedge 3.2 \mathrm{kPa})$ at two temperatures (chosen between $40^{\circ} \mathrm{C}$ and $\left.90^{\circ} \mathrm{C}\right)$. 


\section{Conclusions}

The use of waxes resulting from the processing of plastic waste is a sustainable route, which contributes to minimizing specific environmental impacts and offers added value to the paving technology and the waste management sector. Several characterization tests of these waxes, and their mixtures with different bitumens, were carried out. The analysis of the obtained results allowed the following conclusions:

- HDPE waxes can be produced in a simple reaction system, with relatively low operating costs, which also makes alternative fuels and does not release hazardous compounds into the atmosphere;

- The melting point of these waxes is about $114^{\circ} \mathrm{C}$, and the thermal degradation initiation temperature $\left(\mathrm{T}_{\text {onset }}\right)$ is approximately $450^{\circ} \mathrm{C}$. Both values are similar to those presented by other waxes, which have also been used to modify bituminous binders;

- In the FTIR spectrograms, the PMB with wax showed the characteristic peaks of the oxidative products (carbonyl and sulfoxide), possibly also resulting from ageing during wax mixing, although they were not significant (were minimized due to the inclusion of an anti-oxidant agent);

- When the used wax was blended with a PMB and other functional additives, a reduction in penetration $\left(\mathrm{P} @ 25^{\circ} \mathrm{C}\right)$ of $13 \times 0.1 \mathrm{~mm}$ and an increase in softening point $\left(\mathrm{t}_{\mathrm{RaB}}\right)$ of $18^{\circ} \mathrm{C}$ took place;

- Usually, the addition of waxes can affect the thermal susceptibility of the bituminous binders in an undesired direction but, in this case, thanks to some of the functional additives included, the performance on this parameter was improved $\left(\mathrm{I}_{\mathrm{p}}=4.7\right.$, it was the highest of the studied five different binders);

- The addition of the type of wax used in this study to various types of neat bitumen can lead to reductions in the dynamic viscosity $(\eta)$ of the blends (e.g., around $250 \mathrm{mPa} \cdot \mathrm{s}$ - measured in a 35/50 traditional bitumen at a temperature of $\approx 145^{\circ} \mathrm{C}$ );

- The PMB + wax presented higher complex shear modulus $\left(G^{*}\right)$ values (ranging between $3.6 \mathrm{kPa}$ and $169.4 \mathrm{kPa}$ ) and lower phase angles $(\delta)$ (in the range of 51-68 ${ }^{\circ}$; therefore, it can induce a better rutting resistance. Naturally, these results were also positively influenced by the ageing that occurred while mixing the wax in the PMB;

- After all, in this specific case and after analysing all tests, the binder that incorporated HDPE wax, and other functional additives, could be included in Class 1 of "multigrade paving grade bitumens" (specified in the European standard EN 13924-2 [73]).

This research was part of a broader work, the results of which allowed us to conclude that a "dry pellet supported binder/mastic" is ready to be developed and used together with a conventional bitumen to produce enhanced bituminous mixtures for almost all manufacturing conditions; for example, conditions involving a lack of storage conditions for using modified/special binders. At the same time, it is also possible to contribute to the mitigation of the consequences of climate change through reusing available industrial waste (plastic and others) and reducing energy consumption and gas emissions, while producing the bituminous mixtures and increasing the durability of flexible pavement materials.

It was also confirmed that the bituminous mixtures produced with the developed binder behave more efficiently, and, in general, their direct costs present savings that are not negligible. Furthermore, it can be stressed that plastic waste is inescapable. If non-recyclable plastic waste is used (such as multi-material packaging), its inclusion in bitumen mitigates its incineration or landfilling and contributes to the carbon sequestration in plastics. In this regard, the scaling-up of chemical recycling (which incorporates pyrolysis) is already being highlighted in the Plastics Alliance declaration (https: / / ec.europa. $\mathrm{eu} /$ docsroom/documents/36361/attachments/1/translations/en/renditions/native), accessed on 23 February 2022.

Finally, the studied material has a high potential to be industrialized, allowing more sustainable and resilient products to be used in the paving technology. 
Author Contributions: Conceptualization, F.C.G.M., L.G.P.-S. and F.M.S.L.; methodology, F.C.G.M., L.G.P.-S. and F.M.S.L.; validation, F.C.G.M., L.G.P.-S. and F.M.S.L.; formal analysis, L.G.P.-S., F.M.S.L. and M.A.N.D.A.L.; investigation, F.C.G.M. and E.R.F.S.; writing-original draft preparation, F.C.G.M. and E.R.F.S.; writing-review and editing, L.G.P.-S., F.M.S.L. and M.A.N.D.A.L.; supervision, L.G.P.-S., F.M.S.L. and M.A.N.D.A.L. All authors have read and agreed to the submitted version of the manuscript.

Funding: The authors are grateful to CNPq Ciência sem Fronteiras program for the Grant for Everton Santos, and the Foundation for Science and Technology's funding through project PTDC/EQUEQU/29614/2017, strategic project UID/ECI/04028/2020 from the research unit CERENA, and strategic project UIDB/04625/2020 from the research unit CERIS.

Institutional Review Board Statement: Not applicable.

Informed Consent Statement: Not applicable.

Data Availability Statement: Not applicable.

Acknowledgments: CERENA (Center for Natural Resources and Environment)—Instituto Superior Técnico, Universidade de Lisboa; CERIS (Civil Engineering Research and Innovation for Sustainability)-Instituto Superior Técnico, Universidade de Lisboa; and Transport Laboratory-Department of Civil Engineering-Universidade do Minho-Portugal.

Conflicts of Interest: The authors declare no conflict of interest.

\section{Abbreviations}

The following abbreviations and nomenclature are used in this manuscript:

$\begin{array}{ll}\text { 4PB } & \text { Four-Point Bending tests } \\ \text { DSR } & \text { Dynamic Shear Rheometer } \\ \text { FT/FTW } & \text { Fischer-Tropsch/Fischer-Tropsch wax } \\ \text { FTIR } & \text { Fourier Transform Infrared Spectroscope } \\ \text { FWHM } & \text { Full Width at Half Maximum } \\ \text { HDPE } & \text { High-Density Polyethylene } \\ \text { HMA } & \text { Hot Mix Asphalt } \\ \text { LCW } & \text { Long-Chain Waxes } \\ \text { MBT } & \text { Mechanical and Biological Treatments } \\ \text { MFI } & \text { Melt Flow Index } \\ \text { MSCR } & \text { Multiple Stress Creep Recovery } \\ \text { P/t } \text { taB }_{\text {I }} \text { P } & \text { Penetration grade/Softening point-Ring and Ball method/Penetration index } \\ \text { PAHs } & \text { Polycyclic Aromatic Hydrocarbons } \\ \text { PE/PP/PS } & \text { Polyethylene/Polypropylene/Polystyrene } \\ \text { PEX/XLPE } & \text { Cross-linked Polyethylene } \\ \text { PET } & \text { Poly(Ethylene Terephthalate) } \\ \text { PMB } & \text { Polymer-Modified Bitumen } \\ \text { PO } & \text { Polyolefins } \\ \text { PVC } & \text { Poly(Vinyl Chloride) } \\ \text { RAP } & \text { Reclaimed Asphalt Pavement } \\ \text { ROI } & \text { Return On Investment } \\ \text { RTFOT } & \text { Rolling Thin Film Oven Test } \\ \text { SBS/SIS } & \text { Styrene Butadiene Styrene, Block-Copolymer/Styrene-Isoprene-Styrene } \\ \text { SDG } & \text { Sustainable Development Goals (U.N. 2030 Agenda) } \\ \text { SHRP } & \text { Strategic Highway Research Program (U.S.A.) } \\ \text { TGA/DSC } & \text { Thermogravimetric Analysis/Differential Scanning Calorimeter } \\ \text {T}_{\text {onset }} & \text { Thermal Degradation Initiation Temperature } \\ \text { WEEE } & \text { Waste from Electric and Electronic Equipment } \\ \text { WMA } & \text { Warm Mix Asphalt } \\ \text { WTT } & \text { Wheel-Tracking Test } \\ & \end{array}$




\section{References}

1. Russo, F.; Oreto, C.; Veropalumbo, R. A Practice for the Application of Waste in Road Asphalt Pavements in an Eco-Friendly Way. Appl. Sci. 2021, 11, 9268. [CrossRef]

2. Behnood, A.; Gharehveran, M.M. Morphology, rheology, and physical properties of polymer-modified asphalt binders. Eur. Polym. J. 2019, 112, 766-791. [CrossRef]

3. Nizamuddin, S.; Boom, Y.J.; Giustozzi, F. Sustainable Polymers from Recycled Waste Plastics and Their Virgin Counterparts as Bitumen Modifiers: A Comprehensive Review. Polymers 2021, 13, 3242. [CrossRef]

4. Edwards, Y.; Isacsson, U. Wax in Bitumen. Road Mater. Pavement Des. 2005, 6, 281-309. [CrossRef]

5. Prajapati, R.; Kohli, K.; Maity, S.; Sharma, B. Potential Chemicals from Plastic Wastes. Molecules 2021, 26, 3175. [CrossRef]

6. Wijesekara, D.A.; Sargent, P.; Ennis, C.J.; Hughes, D. Prospects of using chars derived from mixed post waste plastic pyrolysis in civil engineering applications. J. Clean. Prod. 2021, 317, 128212. [CrossRef]

7. Arabiourrutia, M.; Elordi, G.; Lopez, G.; Borsella, E.; Bilbao, J.; Olazar, M. Characterization of the waxes obtained by the pyrolysis of polyolefin plastics in a conical spouted bed reactor. J. Anal. Appl. Pyrolysis 2012, 94, 230-237. [CrossRef]

8. Mishra, N.; Patra, N.; Pandey, S.; Salerno, M.; Sharon, M.; Sharon, M. Taguchi method optimization of wax production from pyrolysis of waste polypropylene. J. Therm. Anal. 2014, 117, 885-892. [CrossRef]

9. Arjanggi, R.D.; Kansedo, J. Recent advancement and prospective of waste plastics as biodiesel additives: A review. J. Energy Inst. 2019, 93, 934-952. [CrossRef]

10. Costa, L.P.D.M.; de Miranda, D.M.V.; de Oliveira, A.C.; Falcon, L.; Pimenta, M.S.S.; Bessa, I.G.; Wouters, S.J.; Andrade, M.; Pinto, J. Capture and Reuse of Carbon Dioxide $\left(\mathrm{CO}_{2}\right)$ for a Plastics Circular Economy: A Review. Processes 2021, 9, 759. [CrossRef]

11. Wu, S.; Montalvo, L. Repurposing waste plastics into cleaner asphalt pavement materials: A critical literature review. J. Clean. Prod. 2021, 280 Pt 2, 124355. [CrossRef]

12. Papari, S.; Bamdad, H.; Berruti, F. Pyrolytic Conversion of Plastic Waste to Value-Added Products and Fuels: A Review. Materials 2021, 14, 2586. [CrossRef] [PubMed]

13. Beghetto, V.; Sole, R.; Buranello, C.; Al-Abkal, M.; Facchin, M. Recent Advancements in Plastic Packaging Recycling: A MiniReview. Materials 2021, 14, 4782. [CrossRef] [PubMed]

14. Czajczyńska, D.; Nannou, T.; Anguilano, L.; Krzyżyńska, R.; Ghazal, H.; Spencer, N.; Jouhara, H. Potentials of pyrolysis processes in the waste management sector. Therm. Sci. Eng. Prog. 2017, 123, 387-394. [CrossRef]

15. Azam, A.M.; El-Badawy, S.M.; Alabasse, R.M. Evaluation of asphalt mixtures modified with polymer and wax. Innov. Infrastruct. Solut. 2019, 4, 43. [CrossRef]

16. Costa, L.M.B.; Peralta, J.; Oliveira, J.R.M.; Silva, H.M.R.D. A New Life for Cross-Linked Plastic Waste as Aggregates and Binder Modifier for Asphalt Mixtures. Appl. Sci. 2017, 7, 603. [CrossRef]

17. Shang, L.; Wang, S.; Zhang, Y.; Zhang, Y. Pyrolyzed wax from recycled cross-linked polyethylene as warm mix asphalt (WMA) additive for SBS modified asphalt. Constr. Build. Mater. 2010, 25, 886-891. [CrossRef]

18. Desidery, L.; Lanotte, M. Effect of Waste Polyethylene and Wax-Based Additives on Bitumen Performance. Polymers 2021, 13, 3733 [CrossRef]

19. Roja, K.L.; Rehman, A.; Ouederni, M.; Krishnamoorthy, S.K.; Abdala, A.; Masad, E. Influence of polymer structure and amount on microstructure and properties of polyethylene-modified asphalt binders. Mater. Struct. 2021, 54, 91. [CrossRef]

20. Porto, M.; Caputo, P.; Loise, V.; Abe, A.A.; Tarsi, G.; Sangiorgi, C.; Gallo, F.; Rossi, C.O. Preliminary Study on New Alternative Binders through Re-Refined Engine Oil Bottoms (REOBs) and Industrial By-Product Additives. Molecules 2021, 26, 7269. [CrossRef]

21. Ghodrat, M.; Alonso, J.A.; Hagare, D.; Yang, R.; Samali, B. Economic feasibility of energy recovery from waste plastic using pyrolysis technology: An Australian perspective. Int. J. Environ. Sci. Technol. 2019, 16, 3721-3734. [CrossRef]

22. Moad, G.; Solomon, D. The Critical Importance of Adopting Whole-of-Life Strategies for Polymers and Plastics. Sustainability 2021, 13, 8218. [CrossRef]

23. Ragaert, K.; Delva, L.; Van Geem, K. Mechanical and chemical recycling of solid plastic waste. Waste Manag. 2017, 69, 24-58. [CrossRef]

24. Capitão, S.; Picado-Santos, L.; Martinho, F. Pavement engineering materials: Review on the use of warm-mix asphalt. Constr. Build. Mater. 2012, 36, 1016-1024. [CrossRef]

25. Rubio, M.C.; Martínez, G.; Baena, L.; Moreno, F. Warm mix asphalt: An overview. J. Clean. Prod. 2012, 24, 76-84. [CrossRef]

26. Chen, J.; Dan, H.; Ding, Y.; Gao, Y.; Guo, M.; Guo, S.; Han, B.; Hong, B.; Hou, Y.; Hu, C.; et al. New innovations in pavement materials and engineering: A review on pavement engineering research 2021. J. Traffic Transp. Eng. 2021, 8, 815-999. [CrossRef]

27. Caputo, P.; Abe, A.A.; Loise, V.; Porto, M.; Calandra, P.; Angelico, R.; Rossi, C.O. The Role of Additives in Warm Mix Asphalt Technology: An Insight into Their Mechanisms of Improving an Emerging Technology. Nanomaterials 2020, 10, 1202. [CrossRef]

28. White, G. A Synthesis on the Effects of Two Commercial Recycled Plastics on the Properties of Bitumen and Asphalt. Sustainability 2020, 12, 8594. [CrossRef]

29. Hung, A.M.; Mousavi, M.; Fini, E.H. Implication of wax on hindering self-healing processes in bitumen. Appl. Surf. Sci. 2020, 523, 146449. [CrossRef]

30. Belc, A.L.; Ciutina, A.; Buzatu, R.; Belc, F.; Costescu, C. Environmental Impact Assessment of Different Warm Mix Asphalts. Sustainability 2021, 13, 11869. [CrossRef] 
31. Martinho, F.C.G.; Farinha, J.P.S. An overview of the use of nanoclay modified bitumen in asphalt mixtures for enhanced flexible pavement performances. Road Mater. Pavement Des. 2017, 20, 671-701. [CrossRef]

32. Martinho, F.C.G. Lab Validation of an Novel Modified Mastic for the Production of More Sustainable Bituminous Mixtures. Ph.D. Thesis, Instituto Superior Técnico-University of Lisbon, Lisbon, Portugal, 2020. (In Portuguese)

33. Santos, E.; Rijo, B.; Lemos, F.; Lemos, M. A catalytic reactive distillation approach to high density polyethylene pyrolysis-Part 2-Middle olefin production. Catal. Today 2020, 379, 212-221. [CrossRef]

34. Santos, E.R.F. Nanostructure Materials as Catalysts for the Degradation of Polyolefins. Ph.D. Thesis, Instituto Superior TécnicoUniversity of Lisbon, Lisbon, Portugal, 2018.

35. Santos, E.; Rijo, B.; Lemos, F.; Lemos, M. A catalytic reactive distillation approach to high density polyethylene pyrolysis-Part 1-Light olefin production. Chem. Eng. J. 2019, 378, 122077. [CrossRef]

36. Gulab, H.; Jan, M.R.; Shah, J.; Manos, G. Plastic catalytic pyrolysis to fuels as tertiary polymer recycling method: Effect of process conditions. J. Environ. Sci. Health Part A 2010, 45, 908-915. [CrossRef] [PubMed]

37. Jixing, L. Study on the Conversion Technology of Waste Polyethylene Plastic to Polyethylene Wax. Energy Sources 2003, 25, 77-82. [CrossRef]

38. Motawie, M.; Hanafi, S.A.; Elmelawy, M.S.; Ahmed, S.M.; Mansour, N.A.; Darwish, M.S.; Abulyazied, D.E. Wax co-cracking synergism of high density polyethylene to alternative fuels. Egypt. J. Pet. 2015, 24, 353-361. [CrossRef]

39. Nanda, S.; Berruti, F. Thermochemical conversion of plastic waste to fuels: A review. Environ. Chem. Lett. 2020, 19, 123-148. [CrossRef]

40. Zeaiter, J. A process study on the pyrolysis of waste polyethylene. Fuel 2014, 133, 276-282. [CrossRef]

41. European Standard EN 13924-1; Bitumen and Bituminous Binders-Specification Framework for Special Paving Grade Bitumen-Part 1: Hard Paving Grade Bitumens. CEN-CENELEC—European Committee for Standardization: Brussels, Belgium, 2015.

42. Norma Portuguesa/European Standard NP EN 12591; Betumes e Ligantes Betuminosos. Especificações Para Betumes de Pavimentação (Bitumen and Bituminous Binders. Specifications for Paving Grade Bitumens). CEN_European Committee for Standardization: Caparica, Portugal, 2011.

43. Norma Portuguesa/European Standard NP EN 14023; Betumes e Ligantes Betuminosos. Quadro de Especificações de Betumes Modificados com Polímeros (Bitumen and Bituminous Binders. Specification Framework for Polymer Modified Bitumens). CEN_European Committee for Standardization: Caparica, Portugal, 2013.

44. Al-Salem, S.M.; Antelava, A.; Constantinou, A.; Manos, G.; Dutta, A. A review on thermal and catalytic pyrolysis of plastic solid waste (PSW). J. Environ. Manag. 2017, 197, 177-198. [CrossRef]

45. EN ISO 11357; Plastics—Differential Scanning Calorimetry (DSC). ISO/CEN: Geneva, Switzerland, 2016.

46. Joohari, I.B.; Giustozzi, F. Hybrid Polymerisation: An Exploratory Study of the Chemo-Mechanical and Rheological Properties of Hybrid-Modified Bitumen. Polymers 2020, 12, 945. [CrossRef]

47. Costa, M.S. Bitumen Regeneration within the Scope of Hot Recycling in a Plant. Ph.D. Thesis, Instituto Superior TécnicoUniversity of Lisbon, Lisbon, Portugal, 2012. (In Portuguese)

48. Weigel, S.; Stephan, D. Differentiation of bitumen according to the refinery and ageing state based on FTIR spectroscopy and multivariate analysis methods. Mater. Struct. 2018, 51, 130. [CrossRef]

49. Hou, X.; Lv, S.; Chen, Z.; Xiao, F. Applications of Fourier transform infrared spectroscopy technologies on asphalt materials. Measurement 2018, 121, 304-316. [CrossRef]

50. Hung, A.M.; Fini, E.H. Absorption spectroscopy to determine the extent and mechanisms of aging in bitumen and asphaltenes. Fuel 2019, 242, 408-415. [CrossRef]

51. Norma Portuguesa/European Standard NP EN 1426; Betumes e Ligantes Betuminosos. Determinação da Penetração com Agulha (Bitumen and Bituminous Binders. Determination of Needle Penetration). CEN-European Committee for Standardization: Caparica, Portugal, 2017.

52. Norma Portuguesa/European Standard NP EN 1427; Betumes e Ligantes Betuminosos. Determinação da Temperatura de Amolecimento. Método do Anel e Bola (Bitumen and Bituminous Binders. Determination of the Softening Point. Ring and Ball Method). CEN_European Committee for Standardization: Caparica, Portugal, 2017.

53. Pereira, P.; Pais, J. Main flexible pavement and mix design methods in Europe and challenges for the development of an European method. J. Traffic Transp. Eng. 2017, 4, 316-346. [CrossRef]

54. European Standard EN 13302; Bitumen and Bituminous Binders-Determination of Dynamic Viscosity of Bituminous Binder Using a Rotating Spindle Apparatus. CEN-CENELEC_European Committee for Standardization: Brussels, Belgium, 2018.

55. European Standard EN 14770; Bitumen and Bituminous Binders-Determination of Complex Shear Modulus and Phase AngleDynamic Shear Rheometer (DSR). CEN_European Committee for Standardization: Brussels, Belgium, 2012.

56. Batista, A.F.; Hofko, B.; De Visscher, J.; Tanghe, T.; da Costa, M.S. Towards improved correlations between bitumen properties and rutting resistance of bituminous mixtures-FunDBitS literature review. IOP Conf. Ser. Mater. Sci. Eng. 2017, $236,012001$. [CrossRef]

57. Rodríguez-Luna, L.; Bustos-Martínez, D.; Valenzuela, E. Two-step pyrolysis for waste HDPE valorization. Process Saf. Environ. Prot. 2020, 149, 526-536. [CrossRef] 
58. Kaya, D.; Topal, A.; Gupta, J.; McNally, T. Aging effects on the composition and thermal properties of styrene-butadiene-styrene (SBS) modified bitumen. Constr. Build. Mater. 2019, 235, 117450. [CrossRef]

59. Tauste-Martínez, R.; Navarro, F.M.M.; Sol-Sánchez, M.; Rubio-Gamez, M.C. Understanding the bitumen ageing phenomenon: A review. Constr. Build. Mater. 2018, 192, 593-609. [CrossRef]

60. Martinho, F.C.G.; Picado Santos, L.G.; Lemos, F.M.S. Novel Modified Recycled Mastic for Demanding and Sustainable Asphalt Mixtures. In ISBM 2020 RILEM Bookseries; Di Benedetto, H., Baaj, H., Chailleux, E., Tebaldi, G., Sauzéat, C., Mangiafico, S., Eds.; Springer: Cham, Switzerland, 2020; Volume 27, pp. 1415-1421. [CrossRef]

61. Tasdemir, Y. High temperature properties of wax modified binders and asphalt mixtures. Constr. Build. Mater. 2009, 23, 3220-3224. [CrossRef]

62. Radhakrishnan, V.; Sri, M.R.; Reddy, K.S. Evaluation of asphalt binder rutting parameters. Constr. Build. Mater. 2018, 173, 298-307. [CrossRef]

63. European Standard EN 16659; Bitumen and Bituminous Binders-Multiple Stress Creep and Recovery Test (MSCRT). CENCENELEC—European Committee for Standardization: Brussels, Belgium, 2015.

64. Chavando, J.A.M.; de Matos, E.C.J.; Silva, V.B.; Tarelho, L.A.; Cardoso, J.S. Pyrolysis characteristics of RDF and HPDE blends with biomass. Int. J. Hydrogen Energy 2021. [CrossRef]

65. Armenise, S.; SyieLuing, W.; Ramírez-Velásquez, J.M.; Launay, F.; Wuebben, D.; Ngadi, N.; Rams, J.; Muñoz, M. Plastic waste recycling via pyrolysis: A bibliometric survey and literature review. J. Anal. Appl. Pyrolysis 2021, 158, 105265. [CrossRef]

66. Moussa, G.; Abdel-Raheem, A.; Abdel-Wahed, T. Effect of Nanoclay Particles on the Performance of High-Density PolyethyleneModified Asphalt Concrete Mixture. Polymers 2021, 13, 434. [CrossRef] [PubMed]

67. Al-Saffar, Z.H.; Yaacob, H.; Katman, H.Y.; Satar, M.K.I.M.; Bilema, M.; Jaya, R.P.; Eltwati, A.S.; Radeef, H.R. A Review on the Durability of Recycled Asphalt Mixtures Embraced with Rejuvenators. Sustainability 2021, 13, 8970. [CrossRef]

68. Porto, M.; Angelico, R.; Caputo, P.; Abe, A.A.; Teltayev, B.; Rossi, C.O. The Structure of Bitumen: Conceptual Models and Experimental Evidences. Materials 2022, 15, 905. [CrossRef]

69. Al-Mansoori, T.; Norambuena-Contreras, J.; Micaelo, R.; Garcia, A. Self-healing of asphalt mastic by the action of polymeric capsules containing rejuvenators. Constr. Build. Mater. 2018, 161, 330-339. [CrossRef]

70. Zhu, J.; Birgisson, B.; Kringos, N. Polymer modification of bitumen: Advances and challenges. Eur. Polym. J. 2014, 54, 18-38. [CrossRef]

71. Crucho, J.; Picado-Santos, L.; Neves, J.; Capitão, S.; Al-Qadi, I.L. Tecnico accelerated ageing (TEAGE)—A new laboratory approach for bituminous mixture ageing simulation. Int. J. Pavement Eng. 2020, 21, 753-765. [CrossRef]

72. Crucho, J.; Picado-Santos, L.; Neves, J.; Capitão, S. The TEAGE ageing method for asphalt mixtures. Transp. Eng. 2020, 2, 100030. [CrossRef]

73. European Standard EN 13924-2; Bitumen and Bituminous Binders-Specification Framework for Special Paving Grade Bitumen-Part 2: Multigrade Paving Grade Bitumens. CEN-CENELEC-European Committee for Standardization: Brussels, Belgium, 2014. 